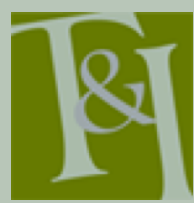

The International Journal for Translation \& Interpreting Research trans-int.org

\title{
Translators' experiences of occupational stress and job satisfaction
}

\author{
Jennifer Courtney \\ Dublin City University \\ jennifer.courtney4@mail.dcu.ie \\ Mary Phelan \\ Dublin City University \\ mary.phelan@dcu.ie
}

DOI: 10.12807/ti.111201.2019.a06

\begin{abstract}
While empirical evidence suggests that interpreters experience high levels of both occupational stress and job satisfaction, there has been little research on the experience of translators. Using a quantitative questionnaire consisting of seven questions, this participant-based study measures the self-perceived occupational stress and job satisfaction levels of 474 translators who are members of the Chartered Institute of Linguists (UK) or the Irish Translators' and Interpreters' Association. Respondents experience stress due to factors such as perceived unfair treatment from agencies, poor remuneration and uncertainty about the future. However, as with interpreters, despite these negatives, respondents generally exhibit high to extremely high job satisfaction.
\end{abstract}

Keywords: freelance translators, in-house translators, job demands, job satisfaction, occupational stress, translator psychology

\section{Introduction}

The field of translation psychology - originally relating to the translation process, and more recently to the translator - has attracted interest in recent years. Jääskeläinen suggests that there "is a psychological angle to most translation-related phenomena" (2012, p. 192). Chesterman (2009) highlights what was then a new focus on translator studies in translation sociology, translation history and in research on translators' decision-making processes. He suggests calling the focus on translators 'the agent model'. BolañosMedina notes that Chesterman focused on sociology rather than psychology and that his ideas would need to be revised "to account for the inclusion of the psychological aspects" (2016, p. 61). She defines translation psychology as "the subdiscipline of Translatology which addresses the study of translators as complex individuals functioning as a whole" (2016, p. 66). She places the study of individual translators in the applied area of organizational psychology, which can focus on macroscopic, meso-organizational, or at a micro level including such matters as the impact of stress on health, motivation and job satisfaction (2016, p. 81).

As outlined below, the focus in Translation Studies research has been mainly on interpreters' occupational stress and job satisfaction, and to date there has been very little on translators' experience of these phenomena. This article reports on a dissertation study conducted by the first author under the supervision of the second author as part of the M.A. in Translation Studies at Dublin City University, and contributes to the field of translation psychology, with particular reference to the area of occupational health psychology. 
It is organised as follows: section 2 reviews previous research on occupational stress and job satisfaction experienced by interpreters and translators. Section 3 outlines the survey design. Section 4 explains how the data was analysed. Section 5 contains the survey results, which are discussed in Section 6.

\section{Previous research}

The relationship between occupational stress and interpreting has been a topic of scholarly interest since the late 1980s, with several studies demonstrating that interpreting is a highly stressful occupation (Heller et al. 1986; Watson 1987). Cooper, Davies, and Tung (1982) were among the first researchers to conduct a large-scale survey of interpreter stress, concluding that conference interpreters in particular are confronted with a great deal of pressure. These findings are supported by Roziner and Shlesinger (2010, p. 219), who investigated remote interpreting at the European Parliament and concluded that "simultaneous interpreting is a particularly stressful occupation, as it requires the interpreter to simultaneously listen, analyse, comprehend, translate, edit and produce a speaker's utterance in real-time." Korpal (2016) investigated the causal relationship between a speaker's rate of delivery and the level of stress experienced by trainee interpreters and concluded that "simultaneous interpreting may indeed be considered a stressful activity" (Korpal 2016, p. 311).

Bontempo and Napier (2011, p. 85) have described a "mini-explosion" of research on sign language (SL) interpreters. With regard to occupational stress, several interview and survey-based studies have reported high levels of stress in SL interpreters (Dean \& Pollard, 2001; McCartney, 2003; Schwenke, 2012; Schwenke et al., 2014). For example, Kao and Craigie's (2013) study of SL interpreters in Taiwan revealed that $85 \%$ of student participants exhibited high stress levels. Furthermore, studies have also shown that burnout among SL interpreters can lead to early departure from the profession, a growing cause for concern (Dean \& Pollard, 2001; Schwenke, 2012; Schwenke et al., 2014).

While it is evident that interpreting is a "highly stress-provoking activity" (Hong, 2003, cited in Kao \& Craigie, 2013, p. 1035), in contrast there has been very little research on translators' experience of stress, the focus of this article. Ruokonen and Mäkisalo (2018) asked translators if they experienced negative, disturbing stress, if deadlines affected the quality of their work and if they had considered changing careers over the previous twelve months. The study found that those who rarely experienced negative stress had a more positive view of their status. Predictably, those who had considered changing careers had a lower perception of their status.

The inverse relationship between occupational stress and job satisfaction has been strongly linked in the literature, in particular in studies of medical and educational staff (Ahsan et al., 2009; Bennett et al., 2005; Cheng et al., 2015; Collie et al., 2015; Leiter et al., 2009; Visser et al., 2003). However, it would appear that similar investigations on translators and interpreters are extremely limited.

Three publications focusing on interpreter satisfaction were found. Although these studies approach the topic from different viewpoints, all three articles reach a similar conclusion: interpreters generally exhibit high levels of job satisfaction. Swartz (1999, p. 134) found that high work satisfaction among sign language interpreters was significantly associated with "a more manageable, lighter, or acceptable workload", while low work satisfaction was found to stem from high supervision and low worker autonomy. The second article investigated job satisfaction in volunteer interpreters working in 
Taiwan with Pan et al. (2012) concluding that knowledge, skill and job characteristics were the highest predictors of job satisfaction for volunteer interpreters. The third article (Lee, p. 2017) involved a survey of 150 professional interpreters in South Korea to examine the impact of individual and job characteristics on job satisfaction. Lee found statistically significant correlations between job satisfaction and such factors as marital status, experience, average working hours and employment type. Job security was the most important factor for respondents.

In terms of translator satisfaction, only one publication focusing on job satisfaction was located. Rodríguez-Castro's 2015 study aimed to develop an instrument for measuring job satisfaction in translators. Although this study does not reveal any significant results in relation to translator satisfaction, Rodriguez-Castro (2015) lists a number of factors - workload, remuneration, supervision, flexibility, deadlines and task satisfaction - that may affect work satisfaction in translators. It is clear that there is currently very little information available on the topic of translators' experience of occupational stress and job satisfaction.

\section{Method}

The questionnaire consisted of seven questions, two of which gathered demographic information on translators' qualifications and experience, while four were statements adapted from previously validated scales from the UK Health Service Executive (HSE) Management Standards Indicator Tool and the US National Institute for Occupational Safety and Health (NIOSH) Generic Job Stress questionnaire. The statements related to job demands, time pressure and workload; work rate; job satisfaction; and possible career change. The final question focused on sources of stress and satisfaction.

A link to the questionnaire hosted on Survey Monkey was circulated by the Irish Translators' and Interpreters' Association and the Chartered Institute of Linguists to their members and a total of 474 respondents completed the questionnaire between $24^{\text {th }}$ May and $19^{\text {th }}$ July 2017.

\section{Data Analysis}

The responses were analysed using descriptive statistics, whereby the basic features of a data set are described and summarised (O'Leary 2014). The results of questions one, two, four and six were tallied and reported as percentages. Questions three and five incorporated Likert scale items, which typically produce ordinal data that can be analysed using measures of central tendency and measures of dispersion (Fink 1995). Finally, as question seven was open-ended and qualitative, a thematic analysis was carried out on the responses which were then categorised by theme and discussed in detail (Braun and Clarke 2006).

\section{Results}

\subsection{Qualifications}

Question one was an open-ended question that invited participants to indicate their qualification(s) or accreditation. Of the 474 respondents, 466 replied to this question. Over half of respondents $(54 \% ; \mathrm{n}=251)$ held a qualification in translation studies, while 209 respondents (45\%) had studied different disciplines such as interpreting studies, modern languages or law. Six 
respondents (1\%) reported having no qualification; their replies included "None. Raised with four languages" and "ten years of experience."

Table 1. Educational qualifications of respondents

\begin{tabular}{ll}
\hline Qualification & Number of responses $(\boldsymbol{n}=\mathbf{4 6 6})$ \\
\hline Bachelors degree or equivalent & 230 \\
Masters degree & 150 \\
Doctorate (Ph.D.) & 26 \\
Diploma in Translation (CloL) & 168 \\
\hline
\end{tabular}

Many respondents provided supplementary, unsolicited information such as award classification and courses taken. For example, nine respondents reported that they were awarded a first class honours degree at undergraduate level, and almost half of respondents $(49 \% ; n=228)$ mentioned several qualifications in their responses. The level of education attained by most respondents was very high - a point that they seemed very eager to establish, perhaps because translators often feel undervalued due to low social status and lack of visibility (Katan, 2009; Sela-Sheffy, 2008; Sela-Sheffy \& Shlesinger, 2011).

\subsection{Experience}

Question two invited respondents to indicate how long they had been working as a translator. This question was included to ascertain whether length of time working in the industry would have an impact on stress and satisfaction levels.

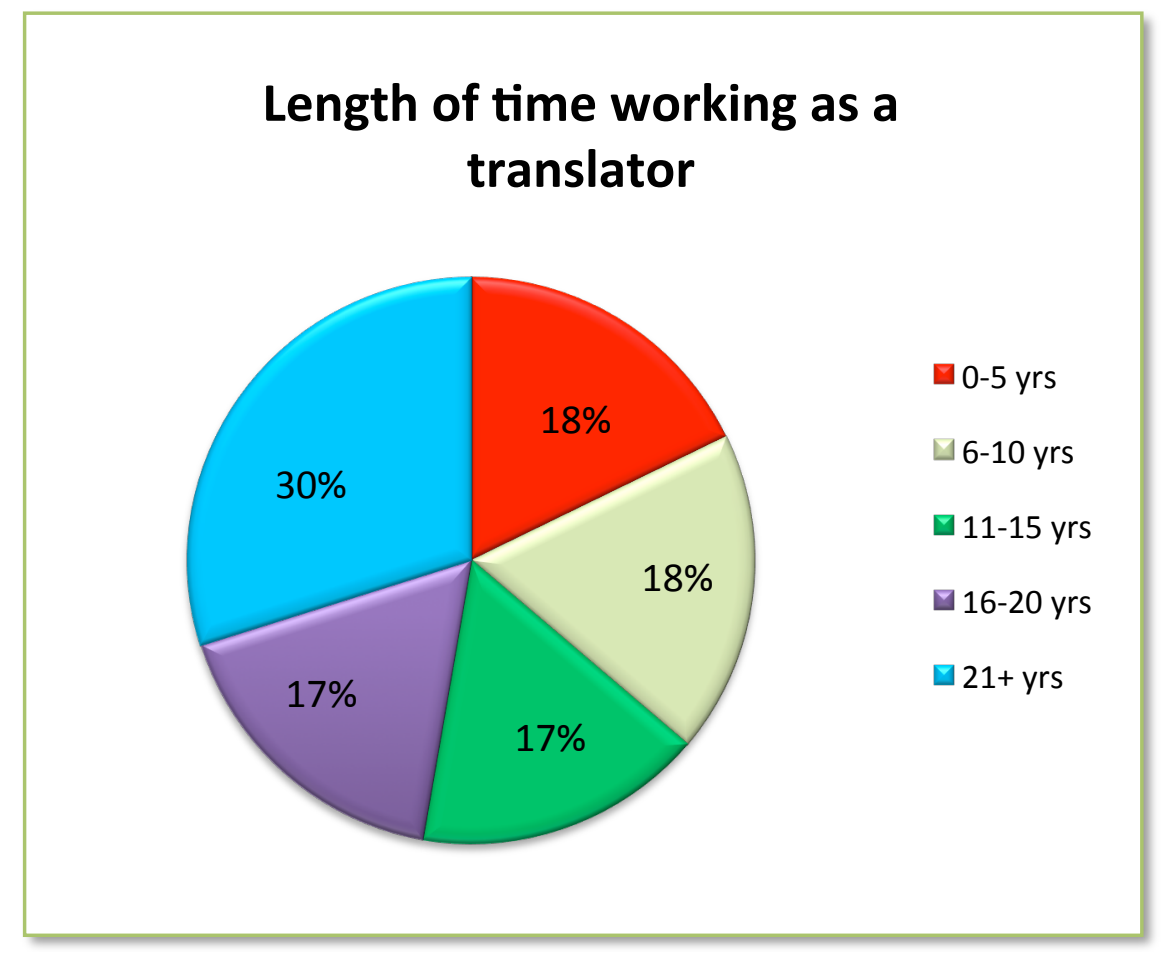

Figure 1. Length of time working as a translator

As seen in Figure 1, responses were distributed quite evenly among the five categories. Of the 472 respondents who answered this question, 84 respondents $(18 \%)$ had been working as a translator for less than five years, while $87(18 \%)$ had been working between six and ten years. Some 78 respondents $(17 \%)$ had been working for $11-15$ years, while $82(17 \%)$ had been working for 16-20 years. The largest group $(n=141)$, accounting for 
almost one-third of respondents, consisted of translators who had been working for more than 21 years.

\subsection{Job demands, time pressures and workload}

Question three invited respondents to reply to six statements regarding job demands, time pressures and workload. Job demands can be defined as "intrinsic task requirements, the level of uncertainty, time pressure, and the amount and difficulty of work" (Cooper \& Payne, 1988, p. 128). Six items were selected from previously validated scales in order to measure occupational stress. These items included: (1) "I am pressured to work long hours"; (2) "I have to work very fast"; (3) "My job rarely allows me to take short breaks during work hours"; (4) "I often have unachievable deadlines"; (5) "I often experience a marked increase in workload"; and (6) "In the last month, I have often felt stressed or anxious due to my job demands."

The results of each item are analysed using measures of central tendency (median values) and response dispersion (percentages), as seen in the tables below.

Table 2. "I am pressured to work long hours"

\begin{tabular}{|l|r|l|r|l|r|r|}
\hline & $\begin{array}{l}\text { Strongly } \\
\text { disagree }\end{array}$ & $\begin{array}{l}\text { Mildly } \\
\text { disagree }\end{array}$ & Neutral & $\begin{array}{l}\text { Mildly } \\
\text { agree }\end{array}$ & $\begin{array}{l}\text { Strongly } \\
\text { agree }\end{array}$ & $\begin{array}{l}\text { Median } \\
\text { values }\end{array}$ \\
\hline$(n=470)$ & $13 \%$ & $15 \%$ & $23 \%$ & $31 \%$ & $18 \%$ & 3 \\
\hline
\end{tabular}

As can be seen in Table 2, most of the 470 respondents who replied to this statement were undecided or neutral $(\mathrm{Mdn}=3)$. While $28 \%$ of respondents $(n=133)$ indicated mild or strong disagreement, almost half of respondents $(49 \% ; n=229)$ agreed with the idea of feeling pressured to work long hours.

Table 3. "I have to work very fast"

\begin{tabular}{|l|c|c|c|c|c|c|}
\hline & $\begin{array}{c}\text { Strongly } \\
\text { disagree }\end{array}$ & $\begin{array}{c}\text { Mildly } \\
\text { disagree }\end{array}$ & Neutral & $\begin{array}{c}\text { Mildly } \\
\text { agree }\end{array}$ & $\begin{array}{c}\text { Strongly } \\
\text { agree }\end{array}$ & $\begin{array}{c}\text { Median } \\
\text { values }\end{array}$ \\
\hline$(n=471)$ & $6 \%$ & $11 \%$ & $20 \%$ & $38 \%$ & $25 \%$ & 4 \\
\hline
\end{tabular}

In Table 3, most respondents expressed mild agreement with the idea of having to work very fast $(\mathrm{Mdn}=4)$. Of the 471 respondents to this statement, the majority $(63 \% ; n=296)$ agreed that they have to work very fast, with a quarter of respondents alone expressing strong agreement. Furthermore, less than $20 \%$ of respondents $(n=82)$ disagreed with this statement.

Table 4. "My job rarely allows me to take short breaks during work hours"

\begin{tabular}{|c|c|c|c|r|r|c|}
\hline & $\begin{array}{c}\text { Strongly } \\
\text { disagree }\end{array}$ & $\begin{array}{c}\text { Mildly } \\
\text { disagree }\end{array}$ & Neutral & $\begin{array}{c}\text { Mildly } \\
\text { agree }\end{array}$ & $\begin{array}{c}\text { Strongly } \\
\text { agree }\end{array}$ & $\begin{array}{c}\text { Median } \\
\text { values }\end{array}$ \\
\hline$(n=472)$ & $26 \%$ & $27 \%$ & $17 \%$ & $19 \%$ & $18 \%$ & 2 \\
\hline
\end{tabular}

The results of Table 4 demonstrate that most respondents mildly disagree with item three $(\mathrm{Mdn}=2)$. When reviewing the percentage dispersion, we can see that over half of respondents $(53 \% ; n=147)$ indicate mild or strong disagreement, i.e. their job does in fact allow for short breaks during working hours. This data reflects the autonomy and flexibility that freelance translators enjoy, a common theme observed in the questionnaire findings.

However, over one third of respondents also expressed mild or strong agreement $(37 \% ; n=147)$. This may be because the results of this item might 
have been skewed, as both in-house and freelance translators participated in the questionnaire. As freelance translators work from home or from a private office, they have more say over their working hours and how many breaks they can take throughout the working day. In-house translators are more restricted in terms of short breaks, as this will depend on company policy.

Table 5. "I often have unachievable deadlines"

\begin{tabular}{|l|c|c|c|c|c|c|}
\hline & $\begin{array}{c}\text { Strongly } \\
\text { disagree }\end{array}$ & $\begin{array}{c}\text { Mildly } \\
\text { disagree }\end{array}$ & Neutral & $\begin{array}{c}\text { Mildly } \\
\text { agree }\end{array}$ & $\begin{array}{c}\text { Strongly } \\
\text { agree }\end{array}$ & $\begin{array}{c}\text { Median } \\
\text { values }\end{array}$ \\
\hline$(n=467)$ & $25 \%$ & $29 \%$ & $17 \%$ & $19 \%$ & $10 \%$ & 2 \\
& 116 & 134 & 80 & 91 & 46 & 2 \\
\hline
\end{tabular}

As seen in Table 5, most respondents expressed mild disagreement with item four. Of the 467 respondents to this item, only $10 \%(n=46)$ expressed strong agreement with the idea of having unachievable deadlines. However, more than half of the translators who answered the question $(54 \% ; n=250)$ disagreed with this statement, with a quarter of respondents expressing strong disagreement.

Table 6. "I often experience a marked increase in workload"

\begin{tabular}{|l|c|c|r|r|r|c|}
\hline & $\begin{array}{c}\text { Strongly } \\
\text { disagree }\end{array}$ & $\begin{array}{c}\text { Mildly } \\
\text { disagree }\end{array}$ & Neutral & $\begin{array}{c}\text { Mildly } \\
\text { agree }\end{array}$ & $\begin{array}{c}\text { Strongly } \\
\text { agree }\end{array}$ & $\begin{array}{c}\text { Median } \\
\text { values }\end{array}$ \\
\hline$(n=472)$ & $9 \%$ & $13 \%$ & $23 \%$ & $34 \%$ & $21 \%$ & 3 \\
& 44 & 59 & 110 & 161 & 98 & 3 \\
\hline
\end{tabular}

The results in Table 6 indicate that most respondents mildly agree that they often experience a marked increase in workload $(\mathrm{Mdn}=4)$. When reviewing the response dispersion, less than a quarter of respondents disagreed with this statement $(22 \% ; n=103)$. However, more than half of respondents indicated mild or strong agreement with the idea $(55 \% ; n=259)$. Again, the results of this item reflect a common theme in the questionnaire findings: freelance translation is generally an unpredictable profession, the flow of work often being described as "feast or famine". This would explain why translators often experience a marked increase in workload.

Table 7. "In the last month, I have often felt stressed or anxious due to my job demands"

\begin{tabular}{|l|c|c|c|c|c|c|}
\hline & $\begin{array}{c}\text { Strongly } \\
\text { disagree }\end{array}$ & $\begin{array}{c}\text { Mildly } \\
\text { disagree }\end{array}$ & Neutral & $\begin{array}{c}\text { Mildly } \\
\text { agree }\end{array}$ & $\begin{array}{c}\text { Strongly } \\
\text { agree }\end{array}$ & $\begin{array}{c}\text { Median } \\
\text { values }\end{array}$ \\
\hline$(n=471)$ & $18 \%$ & $18 \%$ & $18 \%$ & $28 \%$ & $18 \%$ & 3 \\
\hline
\end{tabular}

The results in Table 7 indicate that opinion is much divided on experiences of feeling stressed or anxious due to job demands, with most respondents opting for the neutral middle category $(\mathrm{Mdn}=3)$. While one-third of respondents disagreed with the statement $(36 \% ; n=171)$, almost half of respondents $(46 \% ; n=215)$ expressed agreement, meaning that translators often have felt stressed or anxious in the past month due to job demands.

To conclude, several statements can be deduced from question three. In terms of time pressures, it is clear that the majority of respondents feel they have to work quickly. Half feel that they are pressured to work long hours. However, translators in general are able to take short breaks during work hours.

Furthermore, it was found that unachievable deadlines and increased workload are not a source of occupational stress for freelance translators who 
can determine which projects they take on, and whether a deadline is unreasonable or unsuitable. However, this may not be the case for in-house translators.

Finally, almost half of respondents to this question have often felt stressed or anxious over the past month due to job demands. We can deduce from the results that translators experience medium to high levels of job stress based on their job demands.

\subsection{Work rate}

Question four was a closed question that invited participants to indicate whether they enjoy working quickly and under pressure. Participants were asked to select 'Always', 'Sometimes' or 'Never.' This question, to which 470 respondents replied, was included in order to compare working preferences with job demands. The findings are displayed below in Figure 2.

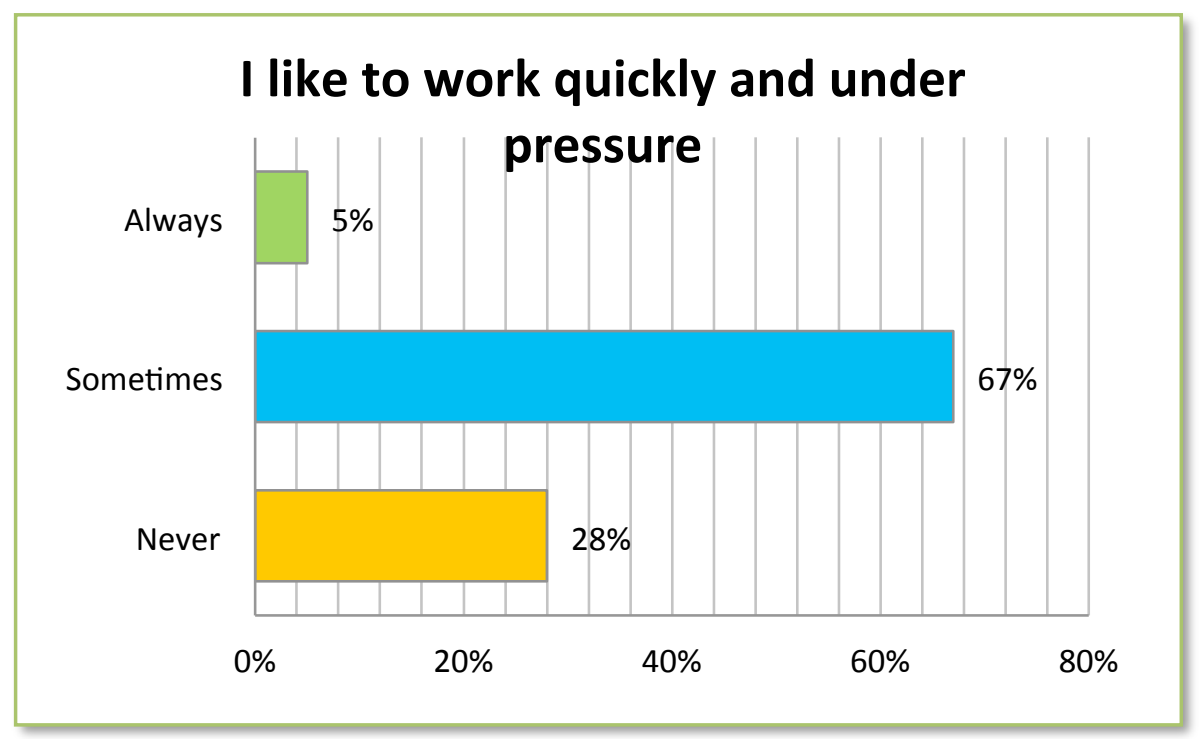

Figure 2. "I like to work quickly and under pressure"

In the previous question, we observed that many respondents feel pressured to work very fast and for long periods. However, when asked whether they like to work in this manner, only $5 \%(n=25)$ of respondents reported that they always enjoy working quickly and under pressure. More than two-thirds of respondents $(67 \% ; n=314)$ stated that they only like to work quickly and under pressure sometimes. However, $28 \%$ of translators $(n=$ 131) reported that they never like to work in this manner. These findings indicate that translator working preferences do not always coincide with their job demands. As such, this may be a source of occupational stress for translators.

\subsection{Job satisfaction}

Question five invited participants to reply to two statements regarding job satisfaction. Job satisfaction can be described as "the cognitive appraisal of the working environment" (Hosie et al., 2006, p. 45). The two statements relating to job satisfaction included: (1) "It would be difficult to find a better job"; and (2) "In general, I am satisfied with my job".

The results of Table 8 clearly demonstrate that most respondents agree with the idea that it would be difficult to find a better job $(\mathrm{Mdn}=4)$. With less than $20 \%$ expressing disagreement $(17 \% ; n=80)$, over half of respondents agreed with this statement $(58 \% ; n=271)$. In fact, the largest response group was 'strongly agree', which attracted one-third of responses for this statement 
$(33 \% ; n=158)$. This clearly indicates a high degree of job satisfaction in translators.

Table 8. "It would be difficult to find a better job"

\begin{tabular}{|l|c|c|c|c|c|c|}
\hline & $\begin{array}{c}\text { Strongly } \\
\text { disagree }\end{array}$ & $\begin{array}{c}\text { Mildly } \\
\text { disagree }\end{array}$ & Neutral & $\begin{array}{c}\text { Mildly } \\
\text { agree }\end{array}$ & $\begin{array}{c}\text { Strongly } \\
\text { agree }\end{array}$ & $\begin{array}{c}\text { Median } \\
\text { values }\end{array}$ \\
\hline$(n=470)$ & $8 \%$ & $9 \%$ & $25 \%$ & $25 \%$ & $33 \%$ & 4 \\
\hline
\end{tabular}

Table 9. "In general, I am satisfied with my job"

\begin{tabular}{|l|c|c|c|c|c|c|}
\hline & $\begin{array}{c}\text { Strongly } \\
\text { disagree }\end{array}$ & $\begin{array}{c}\text { Mildly } \\
\text { disagree }\end{array}$ & Neutral & $\begin{array}{c}\text { Mildly } \\
\text { agree }\end{array}$ & $\begin{array}{c}\text { Strongly } \\
\text { agree }\end{array}$ & $\begin{array}{c}\text { Median } \\
\text { values }\end{array}$ \\
\hline \multirow{2}{*}{$(\boldsymbol{n}=\mathbf{4 7 2})$} & $3 \%$ & $7 \%$ & $10 \%$ & $37 \%$ & $43 \%$ & 4 \\
\hline
\end{tabular}

In Table 9, similar to the previous statement, most translators agreed with the idea of being satisfied with their job $(\mathrm{Mdn}=4)$. In fact, almost half of respondents $(43 \% ; n=203)$ expressed strong agreement with this statement. Only $10 \%$ of respondents expressed dissatisfaction with their jobs.

To conclude, the data set of question five clearly demonstrates that the majority of translators are highly satisfied with their jobs.

\subsection{Possible career change}

Question six was a closed question that invited respondents to indicate if they would like to change career. Respondents were given three options, 'Remain', 'Choose other', or 'Undecided.' Findings from this question, to which 450 respondents replied, are displayed below in Figure 3.

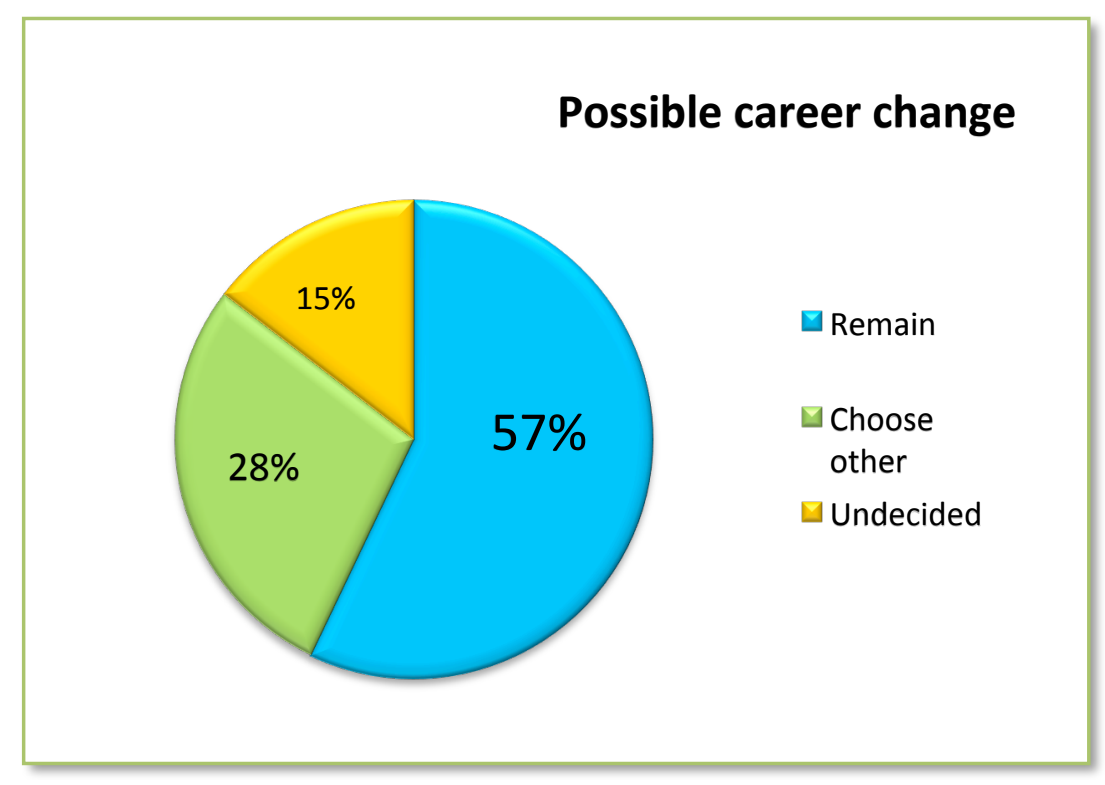

Figure 3. Possible career change

The results indicate that $15 \%$ of respondents $(n=66)$ are undecided, while $28 \%(n=126)$ would choose another career. Although the latter is quite a significant figure, the majority of respondents answering this question reported that they would continue to work as a translator $(57 \% ; n=258)$. The findings of question six complement the results of the previous question, 
demonstrating that despite existing job-related stressors, the majority of translators are satisfied with their current career.

\subsection{Sources of stress and satisfaction for translators}

The final question of the survey was an open-ended question that read: "In your opinion, what are the major sources of stress and satisfaction for translators?" Here, respondents were given the opportunity to freely express their opinion in relation to their occupation. While responses varied greatly, it was possible to identify several recurring themes among the 371 replies. Sources of stress for translators included: (1) poor treatment from agencies and clients, (2) issues with remuneration and self-employment (3) uncertainty about the future, and (4) tight deadlines. Sources of satisfaction included (5) flexibility and autonomy, and (6) the art of translation itself. These themes will be discussed in detail below.

\subsubsection{Poor treatment from agencies and clients}

Here 58 respondents $(16 \%)$ identified poor treatment from translation agencies and clients as one of the main sources of occupational stress. Respondents argued that the constant pressure to reduce pay rates and take on complex, urgent projects leaves translators feeling overwhelmed. Sixteen respondents (4\%) reported that they feel overworked, undervalued, and that they suffer from lack of recognition. Their replies included: "Translation agencies and clients need to value translators more and not treat them like robots" and "Translation is now more like working on an assembly line". Similarly, SelaSheffey (2008), in her study of translator self-perception and status in Israel, found that translators saw themselves as a minor, auxiliary workforce.

Respondents also stated there is a greater focus on "turnaround and cost" than on the quality or value of a translation. One respondent replied, "I am completely fed up with translation agencies. They want to pay virtually nothing and have an excellent job done in 60 minutes". Agencies were also described as "disloyal", "lacking in empathy", and often unwilling to pay translators on time.

Finally, many respondents reported unreasonable expectations and deadlines from clients who were described as "unaware of what translation work entails" and "unwilling to prolong a deadline". However, a number of respondents also maintained that the key to stress reduction is working with direct clients, and establishing good working relationships throughout one's career. In this way, the freelance translator can negotiate or reject unreasonable prices and deadlines. For example, two respondents replied: "I have great clients that are a pleasure to work for, so I don't get stressed" and "I have a good working relationship with my main clients, the result being that I have the confidence to turn down assignments that would put me under undue pressure."

\subsubsection{Issues with remuneration and self-employment}

In terms of remuneration, 48 respondents (12\%) mentioned pay and income as a particular source of stress in the translation industry. Respondents consistently reported that pay rates are decreasing due to rising competition and pressure from clients and agencies. A number of respondents stated that payments are often late and that translation is "badly paid". One respondent replied: "The low status of translators means that we can't charge the remuneration that the expertise and dedication command" and "Despite my top qualification, I cannot make a living out of translation."

In relation to freelance translators, the findings of question seven also indicate that stress can stem from being self-employed. Running a business, marketing one's services, and lack of benefits such as a workplace pension were consistently reported by respondents as stress-inducing factors. For 
example, one respondent explained that: "Stress comes not from the work, but from being self-employed and not having a fixed income or holiday/sick pay."

\subsubsection{Uncertainty about the future}

A third source of occupational stress that emerged from the findings of question seven was 'uncertainty about the future.' A total of 25 respondents (7\%) specifically mentioned that the uncertainty of future projects can prove very stressful for freelance translators; their replies included "stress of having too much work, stress of having too little work" and "lots of or little work, which means there's little prediction of income".

Finally, a further thirteen respondents (4\%) referred to the changing nature of the industry, stating that machine translation and CAT tools are a particular source of occupational stress. According to these respondents, reliance on technology is "driving down income" and "increasing turnaround times". In addition, several respondents shared quite a negative viewpoint in relation to the future of translation, stating, "I feel that the translation industry in the UK has no future" and "the future of the industry is pretty dark."

\subsubsection{Tight deadlines and workload.}

Finally, almost a quarter of respondents $(24 \% ; n=89)$ reported that short and unreasonable deadlines are a significant cause of stress. However, in their replies, most respondents did not agree that deadlines are 'unachievable' per se; this is because freelance translators have the option to accept or decline job offers. Their responses included "I frequently refuse offers because the deadlines are wholly unrealistic" and "I turn work down if I don't think I have enough time to do a good job".

\subsubsection{Flexibility and autonomy}

Interestingly, $20 \%(n=75)$ of respondents to question seven reported high or immense satisfaction, despite the various internal and external stressors associated with translation. Flexibility was reported as one of the main sources of job satisfaction, in particular in relation to being self-employed and having high levels of worker autonomy. Many respondents also stated that being self-employed has allowed them to spend more time raising children or relocate to another country with their partner.

\subsubsection{The art of translation}

Positive feedback from clients was a source of job satisfaction for many respondents. Their replies included: "I feel an immense job satisfaction when I have completed a job and the client is happy" and "satisfaction comes from doing a good job and receiving praise." The art of translation itself and producing high quality texts also gave rise to high levels of job satisfaction for many respondents, giving them a sense of accomplishment. One respondent commented that "there is definite satisfaction in knowing you have translated something well and created a new text." Finally, variety of subject matter and the mental stimulation involved in translation were also reported as sources of work satisfaction.

\section{Discussion}

Using a quantitative survey, the study measured the self-perceived stress and satisfaction levels of 474 professional translators. The level of education attained by translators was generally very high, a point that translators were extremely eager to establish. Many respondents provided lengthy replies that included supplementary, unsolicited information, such as award classification and courses that they had undertaken. Dam and Zethsen (2013) also argue that 
translators generally consider themselves highly skilled experts, yet they do not feel recognised as such. Similar to these findings, perhaps translators also feel undervalued within the industry despite their high-level qualifications and linguistic expertise.

The study's findings show that respondents exhibit medium to high levels of occupational stress. Based on these empirical findings however, one cannot generally conclude that translation is a highly stressful profession. This is because only one stress-inducing factor (job demands) was used to measure stress in translators. Occupational stress is a very complex construct to measure; a longitudinal study incorporating a number of stress-inducing factors would better measure stress levels in translators.

However, it proved possible to conclude a number of generalisable statements in relation to translator job demands. In terms of time pressures, the majority of respondents indicated that they feel pressured to work quickly. In addition, half of respondents reported that they feel pressured to work long hours. Despite these negatives, one positive result was that translators in general feel they are able to take several short breaks during work hours.

In relation to job tasks, it was found that unachievable deadlines and increased workload are not sources of occupational stress for freelance or inhouse translators. This is because freelance translators can decide which projects to take on, i.e. if a deadline is unreasonable or unsuitable, the translator can decline the offer. Many respondents argued that stress levels often depend on the translator's ability to manage project deadlines, and can often be "self-imposed" by taking on too many offers. Furthermore, translators could be assertive and learn to "say no" when agencies and clients request unreasonable completion dates. These findings are consistent with the literature; for example, Malone (2004) argues that work overload can be selfimposed due to lack of assertiveness.

Based on the study's findings, four predictors of occupational stress in translators were found: (1) poor treatment from agencies and clients, (2) issues with remuneration and self-employment (3) uncertainty about the future, and (4) tight deadlines. Many respondents reported that they feel undervalued and overworked, adding that there is a greater focus on "turnaround and cost" rather than on the quality of translation. Translators also consistently reported that pay rates are decreasing due to rising competition and pressure from clients and agencies.

Finally, many respondents referred to the changing nature of the industry, arguing that reliance on technology is "driving down income" and "increasing turnaround times". Interestingly, the growing interest in machine translation and CAT tools is a particular source of occupational stress for many respondents, especially for those who have been working in the industry for many years.

Another issue was whether translators enjoy job satisfaction. The data shows that translators are generally highly satisfied with their occupation. When asked to identify sources of work satisfaction, translators unanimously stated that flexibility, job autonomy and the art of translation itself led to increased levels of job satisfaction.

In response to the question, "to what extent does occupational stress impact job satisfaction", it can be concluded that no relationship was established between these two constructs. Within the literature, certain empirical findings suggest that high levels of work stress are associated with low levels of job satisfaction (Cheng et al., 2015; Landsbergis, 1988; Visser et al., 2003). However, as translators were generally found to exhibit medium to high levels of stress and immense work satisfaction, these findings were not supported.

To summarise the findings of the questionnaire as a whole, one could say that translators experience periods of stress due to their job demands, 
workload and deadlines. However, high levels of job stress in translators appear to stem from other factors outside their control, such as unfair treatment from agencies, poor remuneration, and uncertainty about the future. Paradoxically, however, translators generally exhibit high to immense job satisfaction, an issue that is further explored by Ruokoen and Mäkisalo (2018). These findings echo Katan's $(2009$, p. 82) online questionnaire, which established that although translators were acutely aware of unfair treatment, lack of visibility and status, they were also "extremely satisfied" with their jobs.

To conclude, not only does the present study shed light on the translation industry, but it also provides translators with the opportunity to discuss various issues that they currently face. According to the U.K. Health and Safety Executive (2016), approximately 500,000 people experience workrelated stress at a level that they believe affects their health. In today's highpressure society, it is essential to acknowledge the importance of looking after our mental and physical health, and to work towards creating a society in which professionals are less stressed and even more satisfied with their line of work.

\section{Acknowledgment}

The authors would like to thank the members of the Irish Translators' and Interpreters' Association and the Chartered Institute of Linguists who participated in this study.

\section{References}

Ahsan, N., Abdullah, Z., Yong, D., \& Shah Alem, S. (2009). A study of job stress on job satisfaction among university staff in Malaysia: empirical study. European Journal of Social Sciences, 8(1), 121-129.

Bennett, S., Plint, A., \& Clifford, T.J. (2005). Burnout, psychological morbidity, job satisfaction, and stress: a survey of Canadian hospital based child protection professionals. Arch Dis Child, 90(1), 1112-1116.

Bolaños-Medina, A. (2016). Translation psychology within the framework of Translation Studies: new research perspectives and pedagogical implications. In C. Martín de León \& V. González-Ruiz (Eds.), From the lab to the classroom and back again, 59-99. Frankfurt am Main: Peter Lang.

Bontempo, K., \& Napier, J. (2011). Evaluating emotional stability as a predictor of interpreter competence and aptitude for interpreting. Interpreting: International Journal of Research and Practice in Interpreting, 13(1), 85-105.

Braun, V., \& Clarke, V. (2006). 'Using thematic analysis in psychology' in Qualitative Research in Psychology 3, 77-101.

Cheng, C-Y., Liou, S.R., Tsai, H.N., \& Chang, C.H. (2015). Job stress and job satisfaction among new graduate nurses during the first year of employment in Taiwan. International Journal of Nursing Practice, 21(1), 410-418.

Chesterman, A. (2009). 'The name and nature of translator studies' in Hermes Journal of Language and Communication Studies (42), 13-22.

Collie, R.J., Shapka, J.D., Perry, N.E., \& Martin, A.J. (2015). Teachers' beliefs about social-emotional learning: Identifying teacher profiles and their relations with job stress and satisfaction. Learning and Instruction, 39(1), 148-157.

Cooper, C. L., \& Payne, R. (Eds.). (1988). Causes, coping and consequences of stress at work. Great Britain: Biddles Ltd.

Cooper, C.L., Davies, R. \& Tung, R.L. (1982). Interpreting stress: sources of job stress among conference interpreters. Multilingua, 1(1), 97-108.

Dam, H.V., \& Zethsen, K.K. (2013). Translators in international organisations: a special breed of high-status professionals? Danish EU translators as a case in point. Translation and Interpreting Studies, 15(2), 229-259.

Dean, R., \& Pollard, R. (2001). Application of demand-control theory to sign language interpreting: Implications for stress and interpreter training. Journal of Deaf Studies and Deaf Education, 6(1), 1-13. 
Fink, A. (1995). How to analyse survey data. California: SAGE.

Health and Safety Executive. (2016). Work related stress, anxiety and depression statistics in Great Britain, 2016. Retrieved from http://www.hse.gov.uk/ statistics/causdis/stress/index.htm

Health and Safety Executive. (n.d.). Health Service Executive Management Standards Indicator Tool. Retrieved from http://www.hse.gov.uk/stress/standards/pdfs/ indicatortool.pdf

Heller, B., Stansfield, M., Stark, G., \& Langholtz, D. (1986). Sign language interpreter stress: An exploratory study. Convention of the American Deafness and Rehabilitation Association, 1985. Little Rock: ADARA.

Hong, H. F. (2003). Job stress among conference interpreters in Taiwan. (Unpublished Master's thesis). National Yunlin University of Science and Technology. Yunlin, Taiwan, ROC.

Hosie, P.J., Sevastos, P.P., \& Cooper, C.L. (2006). Happy-performing managers: The impact of affective wellbeing and intrinsic job satisfaction in the workplace. Cornwall: MPG Books Ltd.

Jääskeläinen, R. (2012). Translation psychology. In Y. Gambier \& L. van Doorslaer (Eds.), Handbook of Translation Studies Vol. 3, 191-197. Amsterdam and New York: John Benjamins.

Kao, P.C., \& Craigie, P. (2013). Evaluating student interpreters' stress and coping strategies. Social Behaviour and Personality, 41(6), 1035-1044.

Katan, D. (2009). Occupation or profession: A survey of the translator's world. Translation and Interpreting Studies, 4(2), 187-209.

Korpal, P. (2016). Interpreting as a stressful activity: Physiological measures of stress in simultaneous interpreting. Poznań Studies in Contemporary Linguistics, 52(2) 297-316.

Landsbergis, P.A. (1988). Occupational stress among health care workers: A test of the job demands-control model. Journal of Organizational Behaviour, 9(1), 217239.

Lee, J. (2017) Professional interpreters' job satisfaction and relevant factors: A case study of trained interpreters in South Korea. Translation and Interpreting Studies, 12(3), 427-448.

Leiter, M.P., Frank, E., \& Matheson, T.J. (2009). Demands, values, and burnout relevance for physicians. Canadian Family Physician, 55 (1), 1224-1225.

Malone, S.A. (2004). Surviving stress: A guide for managers and employees. Cork: Oak Tree Press.

McCartney, J. L. (2003). The development of a profile to predict high and low-risk burnout for sign language interpreters: A comparative study of educational and community interpreters. (Unpublished PhD thesis). University of Akron.

National Institute for Occupational Safety and Health (NIOSH). (2017). Generic Job Stress Questionnaire. Retrieved from https:/www.cdc.gov/niosh/topics/workorg/ tools/pdfs/NIOSH-Generic-Job-Stress-Questionaire.pdf

O'Leary, Z. (2014). The essential guide to doing your research project $\left(2^{\text {nd }}\right.$ ed.). London: SAGE.

Pan, S.L., Wu, H.C., Chou, J., \& Simpson, S. (2012). Influence of activity involvement and place attachment on volunteer interpreters' satisfaction in Taiwan. Journal of Interpretation Research, 17(2), 7-22.

Rodriguez Castro, M. (2015). Conceptual construct and empirical validation of a multifaceted instrument for translator satisfaction. The International Journal for Translation and Interpreting Research, 7(2), 30-50.

Roziner, I., \& Shlesinger, M. (2010). Much ado about something remote: stress and performance in remote interpreting. Interpreting: International Journal of Research and Practice in Interpreting, 12(2), 214-247.

Ruokonen, M., \& Mäkisalo, J. (2018). Middling-status profession, high-status work: Finnish translators' status perceptions in the light of their backgrounds, working conditions and job satisfaction. Translation and Interpreting, 10 (1), 1-17.

Schwenke, T.J. (2012). Sign language interpreters and burnout. Journal of Interpretation, 20(1), 1-13.

Schwenke, T.J., Ashby, J.S., \& Gnilka, P.B. (2014). Sign language interpreters and burnout: The effects of perfectionism, perceived stress, and coping resources. Interpreting: International Journal of Research and Practice in Interpreting, 16(2), 209-232. 
Sela-Sheffy, R. (2008). On the status and professional self-perceptions of translators in Israel. Retrieved from https://m.tau.ac.il/ rakefet/papers/RS-IsraeliTranslators $\% 5$ BIstanbul2008\%5D.pdf

Sela-Sheffy, R., \& Shlesinger, M. (Eds.). (2011). Identity and status in the translational professions. Amsterdam: John Benjamins.

Swartz, D. (1999). Job satisfaction of interpreters for the deaf. (Unpublished PhD thesis). The Graduate School of America, Minnesota. Retrieved from https://www.academia.edu/17442124/Job_Satisfaction_of_Interpreters_for_the Deaf

Visser, R.M., Smets, E., Oort, F.J., \& C.J.M. de Haes, H. (2003). Stress, satisfaction and burnout among Dutch medical specialists. Canadian Medical Association Journal, 168(3), 271-275.

Watson, J. (1987). Interpreter burnout. Journal of Interpretation, 4(1), 79-85. 